\title{
Attenuated Total Reflectance-FTIR Spectra Combined with Multivariate Calibration and Discrimination Analysis for Analysis of Patchouli Oil Adulteration
}

\author{
Zaki Fahmi ${ }^{1}$, Mudasir ${ }^{1}$, and Abdul Rohman ${ }^{2,3, *}$ \\ ${ }^{1}$ Department of Chemistry, Faculty of Mathematics and Natural Sciences, Universitas Gadjah Mada, \\ Sekip Utara, Yogyakarta 55281, Indonesia \\ ${ }^{2}$ Department of Pharmaceutical Chemistry, Faculty of Pharmacy, Universitas Gadjah Mada, \\ Sekip Utara, Yogyakarta 55281, Indonesia \\ ${ }^{3}$ Institute of Halal Industry and Systems, Universitas Gadjah Mada, Sekip Utara, Yogyakarta 55281, Indonesia
}

*Corresponding author:

email:abdul_kimfar@ugm.ac.id

Received: July 12, 2018

Accepted: February 3, 2019

DOI: $10.22146 / \mathrm{ijc} .36955$

\begin{abstract}
The adulteration of high priced oils such as patchouli oil with lower price ones is motivated to gain the economical profits. The aim of this study was to use FTIR spectroscopy combined with chemometrics for the authentication of patchouli oil ( $\mathrm{PaO})$ in the mixtures with Castor Oil (CO) and Palm Oil (PO). The FTIR spectra of PaO and various vegetable oils were scanned at mid infrared region (4000-650 $\left.\mathrm{cm}^{-1}\right)$, and were subjected to principal component analysis (PCA). Quantitative analysis of $\mathrm{PaO}$ adulterated with $C O$ and $P O$ were carried out with multivariate calibration of Partial Least Square (PLS) regression. Based on PCA, PaO has the close similarity to CO and PO. From the optimization results, FTIR normal spectra in the combined wavenumbers of 1200-1000 and 3100-2900 $\mathrm{cm}^{-1}$ were chosen to quantify PaO in PO with coefficient of determination $\left(R^{2}\right)$ value of 0.9856 and root mean square error of calibration (RMSEC) of $4.57 \%$ in calibration model. In addition, $R^{2}$ and root mean square error of prediction (RMSEP) values of 0.9984 and $1.79 \%$ were obtained during validation, respectively. The normal spectra in the wavenumbers region of 1200-1000 $\mathrm{cm}^{-1}$ were preferred to quantify $\mathrm{PaO}$ in $\mathrm{CO}$ with $\mathrm{R}^{2}$ value of 0.9816 and RMSEC of $6.89 \%$ in calibration, while in validation model, the $R^{2}$ value of 0.9974 and RMSEP of $2.57 \%$ were obtained. Discriminant analysis was also successfully used for classification of $\mathrm{PaO}$ and $\mathrm{PaO}$ adulterated with PO and CO without misclassification observed. The combination of FTIR spectroscopy and chemometrics provided an appropriate model for authentication study of $\mathrm{PaO}$ adulterated with $\mathrm{PO}$ and $\mathrm{CO}$.
\end{abstract}

Keywords: infrared spectroscopy; chemometrics; patchouli oil; castor oil; palm oil

\section{- INTRODUCTION}

Patchouli Oil $(\mathrm{PaO})$ is an essential oil obtained from dried and fermented young leaves of Pogostemon cablin (Blanco) Benth, a perennial herb belonging to family Lamiacae and widely distributed in regions of tropical and subtropical, prior to be subjected to steam distillation. The yield of oil is typically 2-3\% [1]. The oil is an important natural material used in the industries of perfumery, food, and has been historically used to repel clothes moths and as a cold treatment in Asia [2]. The major component composed of $\mathrm{PaO}$ is patchouli alcohol, a natural tricyclic sesquiterpene isolated from volatile oil of $\mathrm{PaO}$. Patchouli Oil has been reported to have some biological activities such as anti-inflammatory [3], anti-oxidative [4], antitumor [5], antibacteria, antifungus and antivirus [6-8], as well as as whitening agent [9]. The oil has high priced value in oil industry, therefore, $\mathrm{PaO}$ is subjected to be adulterated with other oils to gain economical profit.

The adulteration practice of essential oils is an emerging issue currently, not only for consumers but also for producers and regulatory bodies [10]. This practice included the addition of cheaper essential oils, 
addition of vegetable oils such as castor oil and palm oils to increase the weight of essential oils and total or partial substitution of the original plant sources by other plants [11]. In order to assure quality, safety, and the authenticity of essential oils, different analytical techniques are needed. As a consequence, several analytical methods have been reported for the authentication of essential oils including organoleptic, physical, chemical, spectroscopic and chromatographic-based methods [12-15]. Fourier Transform Infrared (FTIR) spectroscopy is promising technique for authentication of essential oils due to its property as fingerprint analytical technique [16]. The fingerprinting analysis of essential oils represented qualitative approach to plant species authentication as well as quality evaluation [17].

FTIR spectroscopy in combination with chemometrics techniques have been reported for authentication of four essential oils namely wintergreen, rosemary, tea tree, and lemon eucalyptus oils adulterated with either lemongrass essential oil or peppermint essential oil [18], authentication of origano, thyme, and chamomile [18], geographical origin of lavandin var. Grosso essential oils [19], and authentication of camellia oil [20]. Few studies have been reported the authentication of patchouli oil, especially using FTIR spectroscopy. Therefore, this study was intended to use FTIR spectroscopy in combination with chemometrics of multivariate calibration of Partial Least Square (PLS) and Discriminant Analysis (DA) for the authentication of patchouli oil.

\section{- EXPERIMENTAL SECTION}

\section{Materials}

Patchouli oil was purchased from CV. Surya Wulan (Yogyakarta, Indonesia). Olive oil, palm oil, castor oil and other oils used in this study were purchased from supermarkets around Yogyakarta, Indonesia. The solvents and reagents used were of pro-analytical grade and were purchased from Merck (Darmstadt, Germany).

\section{Procedure}

\section{Compositional analysis of patchouli oil}

The compositional analysis of patchouli oil was performed using gas chromatography-mass spectrometry (GC-MS). Patchouli oil $(1 \mu \mathrm{L})$ was injected into Gas Chromatography GC-2014 (Shimadzu GC2010, Shimadzu Corp., Tokyo, Japan) under the following conditions: DB- 5 capillary column $(30 \mathrm{~m} \times 0.25 \mathrm{~mm}$ I.D. and $0.25 \mu \mathrm{m}$ tickness; Agilents, Tokyo, Japan); carrier gas of He with $12.0 \mathrm{kPa}$ with flow rate of $50 \mathrm{~mL} / \mathrm{min}$; a column temperature was set from $50-240^{\circ} \mathrm{C}$ with rate of $5{ }^{\circ} \mathrm{C} / \mathrm{min}$, and the temperature was hold at $240{ }^{\circ} \mathrm{C}$ for $19 \mathrm{~min}$; injection temperature of $250{ }^{\circ} \mathrm{C}$; detection temperature of $320^{\circ} \mathrm{C}$. Helium was used as the carrier gas. GC-mass spectrometry (GC-MS) data were collected with a GCMS-QP 2010 (Shimadzu, Japan) under the following conditions: DB-1 capillary column $(30 \mathrm{~m} \times$ $0.25 \mathrm{~mm}$ I.D. and $0.25 \mu \mathrm{m}$; GL Sciences, Tokyo, Japan); column temperature from $50{ }^{\circ} \mathrm{C}(1 \mathrm{~min})$ to $320{ }^{\circ} \mathrm{C}$ at $5{ }^{\circ} \mathrm{C} / \mathrm{min}$; injector temperature of $260^{\circ} \mathrm{C}$ with split ratio of 1:50; MS detector temperature was set of $320^{\circ} \mathrm{C}$ with acquisition mass range of 40-500 amu. Components were identified using the comparison of the experimental GCMS data with authentic compounds or the NIST MS library. Quantification of volatile compounds was determined using relative percentage, known as internal normalization technique.

\section{Quantitative analysis of patchouli oil using FTIR spectroscopy}

For quantitative analysis of patchouli oil $(\mathrm{PaO})$ in the mixture with castor oil (CO) and palm oil (PO), a set of 21 calibration samples consisting of $\mathrm{PaO}-\mathrm{CO}$ and $\mathrm{PaO}-\mathrm{PO}$ in certain concentration covering $1.0-50.0 \%$ $(\mathrm{v} / \mathrm{v})$ was prepared. Another independent samples called with validation samples were also prepared. All samples were scanned using FTIR spectrophotometer.

\section{Classification of PaO and PaO adulterated with CO and $\mathrm{PO}$}

Classification of $\mathrm{PaO}$ and $\mathrm{PaO}$ adulterated with $\mathrm{CO}$ and PO was carried out using discriminant analysis by preparing at concentration range of $1-50 \%$ of $\mathrm{CO}$ and PO. All pure $\mathrm{PaO}$ and $\mathrm{PaO}$ mixed with $\mathrm{CO}$ and $\mathrm{PO}$ were assigned as "unadulterated" and "adulterated", respectively. 


\section{FTIR spectra measurement}

FTIR spectra of were measured using FTIR spectrophotometer Nicolet 6700 equipped with detector of deuterated triglycine sulphate (DTGS) and beam splitter of $\mathrm{KBr} / \mathrm{Germanium}$. This instrument was interfaced to computer operating systems which include OMNIC operating system (Version 7.0 Thermo Nicolet) software. The sampling compartment was horizontal Attenuated Total Reflectance kit composed of ZnSe crystal. All FTIR spectra of tested samples were scanned at wavenumbers of $4000-650 \mathrm{~cm}^{-1}$ ), using 32 scans with 4 $\mathrm{cm}^{-1}$ resolution. These spectra were recorded as absorbance mode at each data point in triplicate.

\section{Data analyses}

The software of TQ Analyst ${ }^{\mathrm{TM}}$ version 6 was used for the treatment of multivariate calibration of Partial Least Square (PLS) and Discriminant Analysis (DA). The spectral regions where the variations were observed were chosen during analysis (PLS and DA). In addition, Minitab software version 17 was used for principal component analysis (PCA).

\section{- RESULTS AND DISCUSSION}

Each edible fats and oils are mainly composed from triglycerides (nearly 98\%) along with some minor components including sterols, tocopherols, lipid-soluble vitamins, and other components in trace levels. The characterization of patchouli oil $(\mathrm{PaO})$ was performed by determining volatile components present using Gas Chromatography-Mass Spectrometer (GC-MS), while palm and castor oils were characterized based on fatty acid composition. Table 1 revealed the volatile components in $\mathrm{PaO}$, in which Patchouli alcohol was the main components accounting of $15.80 \%$. The levels of volatile components were comparable with those reported by Akhila and Tewari [2]. Therefore, it can be concluded that the used $\mathrm{PaO}$ was not previously mixed with other components.

In order to decide the oil models used as adulterant in $\mathrm{PaO}$, principal component analysis (PCA) was used. Fig. 1 showed PCA score plot using absorbance values at whole mid infrared region $\left(4000-650 \mathrm{~cm}^{-1}\right)$ as variables, representing the projection of samples defined by the first

Table 1. The composition of volatile components in patchouli oil as determined using gas chromatography-mass spectrometry

\begin{tabular}{lcc}
\hline \multirow{2}{*}{ Volatile components } & \multicolumn{2}{c}{ Concentration (\%) } \\
\cline { 2 - 3 } & Present study & Akhila and Tewari [2] \\
\hline$\alpha$-pinene & 0.24 & $0.001-0.3$ \\
$\beta$-pinene & 0.57 & $0.02-1$ \\
Limonene & 0.05 & $0.01-0.3$ \\
$\lambda$-elemene & - & $0.01-1.9$ \\
$\beta$-patchoulene & - & $0.03-12$ \\
$\beta$-elemene & - & $0.18-1.9$ \\
Cycloseychellene & - & $0.02-0.8$ \\
$\beta$-caryophyllene & - & $0.75-6.8$ \\
$\alpha$-Guaiene & 18.56 & $2.9-23$ \\
Seychellene & 14.88 & $2.3-13$ \\
$\alpha$-humulene & 3.69 & $0.05-2$ \\
$\alpha$-patchoulene & 1.89 & $1.2-13$ \\
Germacrene & - & $0.00-0.2$ \\
Aciphyllene & 5.53 & $0.7-4.2$ \\
$\alpha$-bulnesene & 14.14 & $2.9-23$ \\
Caryophyllene oxide & 0.60 & $0.0-4.6$ \\
Pogostol & - & $0.2-6.2$ \\
Patchouli alcohol & 15.80 & $11-72$ \\
\hline
\end{tabular}

Zaki Fahmi et al. 
Principle Component (PC 1) and the second Principle Component (PC 2). Among studied oils having low price values in the market, castor oil and palm oil had close similarity with $\mathrm{PaO}$, therefore both oils were preferred as oil adulterants in $\mathrm{PaO}$.

\section{Quantitative Analysis of Adulterants in Patchouli Oil}

In this study, authentication of $\mathrm{PaO}$ was carried out by quantifying $\mathrm{PaO}$ in the binary mixture with castor oil and palm oil using multivariate calibration and classifying $\mathrm{PaO}$ and $\mathrm{PaO}$ mixed with castor oil and palm oil using discriminant analysis using absorbance values at selected wavenumbers. Fig. 2 revealed FTIR spectra of patchouli

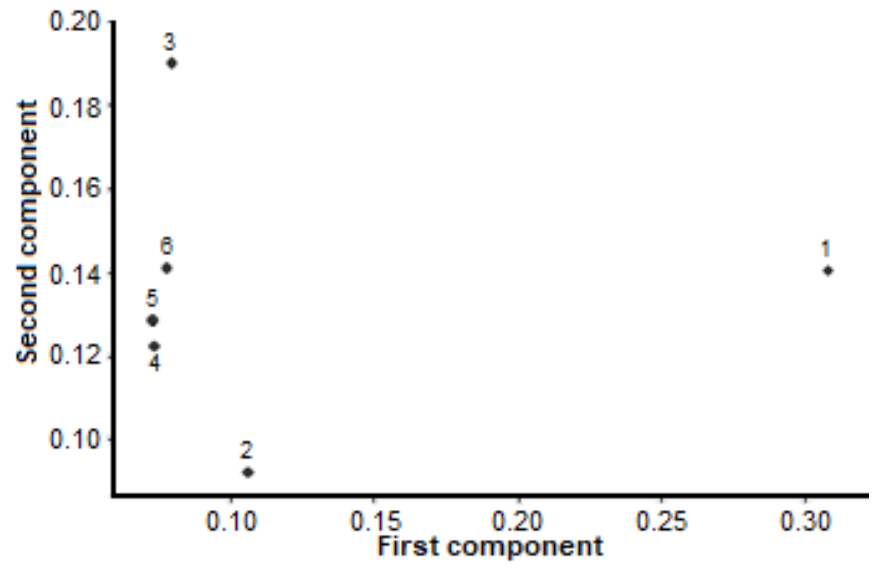

Fig 1. The PCA score plot of patchouli oil and some vegetable oils. (1) patchouli oil; (2) castor oil; (3) palm oil; (4) soybean oil; (5) corn oil and (6) coconut oil

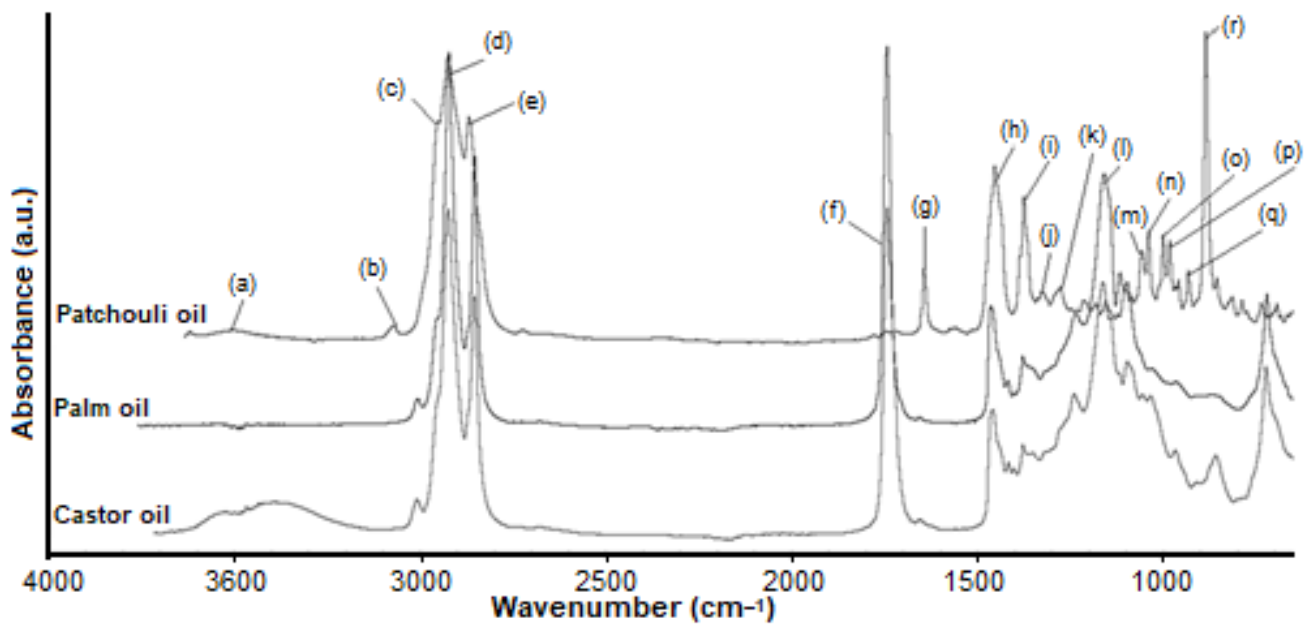

Fig 2. FTIR spectra of patchouli oil, palm oil and castor oil, scanned at mid infrared region $\left(4000-650 \mathrm{~cm}^{-1}\right)$

Table 2. The functional groups responsible for infrared absorptions at wavenumbers of $4000-650 \mathrm{~cm}^{-1}$ [23-24]

\begin{tabular}{lll}
\hline Assignment & Wavenumber $\left(\mathrm{cm}^{-1}\right)$ & Functional groups and modes of vibration \\
\hline (a) & 3503 & $\mathrm{O}-\mathrm{H}$ bonding, stretching \\
(b) & 3069 & cis $\mathrm{C}=\mathrm{CH}$ Stretching \\
(c) and (e) & 2953 and 2875 & methyl $\left(-\mathrm{CH}_{3}\right)$ asymmetric and symmetric stretching vibration \\
(d) & 2922 & methylene $\left(-\mathrm{CH}_{2}\right)$ asymmetric stretching vibration \\
(f) & 1741 & carbonyl $(\mathrm{C}=\mathrm{O})$ stretching vibration, especially guaiene and seychellene \\
(g) & 1643 & cis $\mathrm{C}=\mathrm{C}$, stretching \\
(h) & 1453 & $-\mathrm{CH}_{2}$ (methylene), Bending (scissoring) \\
(i) & 1374 & $-\mathrm{CH}_{3}$ (methyl), Bending \\
(j) & 1278 & $\mathrm{C}-\mathrm{O}$ alcohol, bending \\
(k) and (l) & 1117 and 1097 & $\mathrm{C}-\mathrm{O}$ ether, bending \\
(m), (n), (o), and (p) & $1057,1039,1032$, and 999 & $\mathrm{C}-\mathrm{O}$ ether, bending \\
(q) & 982 & $-\mathrm{HC}=\mathrm{CH}-($ trans $)$, out of plane \\
(r) & 885 & $-\mathrm{HC}=\mathrm{CH}-($ cis $)$, out of plane \\
\hline
\end{tabular}


oil and the oil adulterants (castor oil and palm oil) at mid infrared region of 4000-650 $\mathrm{cm}^{-1}$. Each bands and shoulder are corresponding to absorption of infrared radiation by functional groups present in $\mathrm{PaO}, \mathrm{CO}$ and $\mathrm{PO}$, as compiled in Table 2. The variation in FTIR spectra existed in $\mathrm{PaO}$, $\mathrm{CO}$ and $\mathrm{PO}$ was exploited for selecting wavenumbers region used for quantitative and classification analyses.

Quantitative analysis of $\mathrm{PaO}$ in palm oil and castor oil was facilitated with the commonly used of multivariate calibration, namely Partial Least Square (PLS) regression. This regression was based on inverse regression in which concentration in $y$-axis was modelled using predictors of principle components, a linear combination of absorbance values in $x$-axis [21]. To get the optimum prediction, the optimization process in terms of selection of wavenumbers and FTIR spectral treatments offering best prediction models was performed. The wavenumbers selected to be optimized was based on the variation existed between $\mathrm{PaO}$ and oil adulterants ( $\mathrm{CO}$ and $\mathrm{PO})$. Table 3 revealed the optimization results using different wavenumbers regions and FTIR spectral treatments. Because of its highest values of $R^{2}$ and lowest values of RMSEC and RMSEP, $\mathrm{PaO}$ in palm oil was quantified using normal spectra using variables of absorbance values at combined wavenumbers region of $1200-1000 \mathrm{~cm}^{-1}$.

Similarly, Table 4 exhibited the results of quantification of $\mathrm{PaO}$ in castor oils using PLS regression with different wavenumbers and FTIR spectra models. Fig. 3 showed PLS regression models for the relationship between actual values of $\mathrm{PaO}(x$-axis) and FTIR predicted values $(y$-axis) in either calibration or validation using wavenumbers region of $1200-1000 \mathrm{~cm}^{-1}$. The equations obtained were $\mathrm{y}=0.9636 \mathrm{x}+1.8435\left(\mathrm{R}^{2}\right.$ of $0.9738)$ in calibration, and $y=0.9414 x+2.9902\left(R^{2}=\right.$ 0.9984) in validation models, respectively. Residual analyses revealed that the difference between actual and predicted values fallen near zero, indicating that systematic errors were negligible.

Table 3. The performance of partial least square regression for quantification of patchouli oil in in palm oil

\begin{tabular}{|c|c|c|c|c|c|c|}
\hline \multirow{2}{*}{ Frequency region $\left(\mathrm{cm}^{-1}\right)$} & \multirow{2}{*}{$\begin{array}{l}\text { Spectral } \\
\text { treatment }\end{array}$} & \multirow{2}{*}{$\begin{array}{l}\text { Number } \\
\text { of factors }\end{array}$} & \multicolumn{2}{|c|}{ Calibration } & \multicolumn{2}{|c|}{ Validation } \\
\hline & & & $\mathrm{R}^{2}$ & RMSEC (\%) & $\mathrm{R}^{2}$ & RMSEP (\%) \\
\hline $943-863$ and $1069-1033$ & Normal & 3 & 0.9875 & 4.72 & 0.9999 & 4.33 \\
\hline $1200-1000$ and $3100-2900^{*}$ & Normal & 5 & 0.9901 & 4.20 & 0.9999 & 2.14 \\
\hline $1200-1000$ & Normal & 2 & 0.9862 & 4.96 & 0.9998 & 2.15 \\
\hline $3100-2900$ & Normal & 2 & 0.9821 & 5.65 & 0.9999 & 3.97 \\
\hline $885-857,982-964$ and $1039-983$ & First derivative & 2 & 0.9870 & 4.82 & 1.000 & 3.65 \\
\hline $1200-1000$ and $3100-2900$ & First derivative & 2 & 0.9865 & 4.92 & 0.9999 & 4.11 \\
\hline $1200-1000$ & First derivative & 2 & 0.9873 & 4.77 & 0.9999 & 4.18 \\
\hline $3100-2900$ & First derivative & 2 & 0.9834 & 5.43 & 1.000 & 3.81 \\
\hline
\end{tabular}

${ }^{\star}$ Bold $=$ selected for quantification

Table 4. The performance of partial least square regression for quantification of patchouli oil in in castor oil

\begin{tabular}{lcccccc}
\hline \multirow{2}{*}{ Frequency region $\left(\mathrm{cm}^{-1}\right)$} & \multirow{2}{*}{$\begin{array}{c}\text { Spectral } \\
\text { treatment }\end{array}$} & $\begin{array}{c}\text { Number } \\
\text { of factors }\end{array}$ & \multicolumn{2}{c}{ Calibration } & \multicolumn{2}{c}{ Validation } \\
\cline { 5 - 7 } & Normal & 2 & 0.9684 & 7.07 & 0.9974 & 4.23 \\
870-811, 928-873 and 940-929 & Normal & 2 & 0.9694 & 7.56 & 0.9982 & 3.62 \\
1200-1000 and 3100-2900 & Normal & $\mathbf{4}$ & $\mathbf{0 . 9 7 3 8}$ & $\mathbf{6 . 8 9}$ & $\mathbf{0 . 9 9 7 4}$ & $\mathbf{2 . 5 7}$ \\
$\mathbf{1 2 0 0 - 1 0 0 0}$ & Normal & 2 & 0.9512 & 10.1 & 0.9985 & 9.35 \\
$3100-2900$ & First derivative & 2 & 0.9693 & 7.57 & 0.9970 & 2.60 \\
906-878, 1107-1093 and 1179-1163 & First derivative & 2 & 0.9677 & 7.64 & 0.9979 & 5.30 \\
$1200-1000$ and 3100-2900 & First derivative & 1 & 0.9650 & 7.95 & 0.9981 & 6.00 \\
$1200-1000$ & First derivative & 2 & 0.9562 & 8.87 & 0.9982 & 8.36 \\
$3100-2900$ & & & & & &
\end{tabular}

${ }^{\star}$ Bold $=$ selected for quantification 

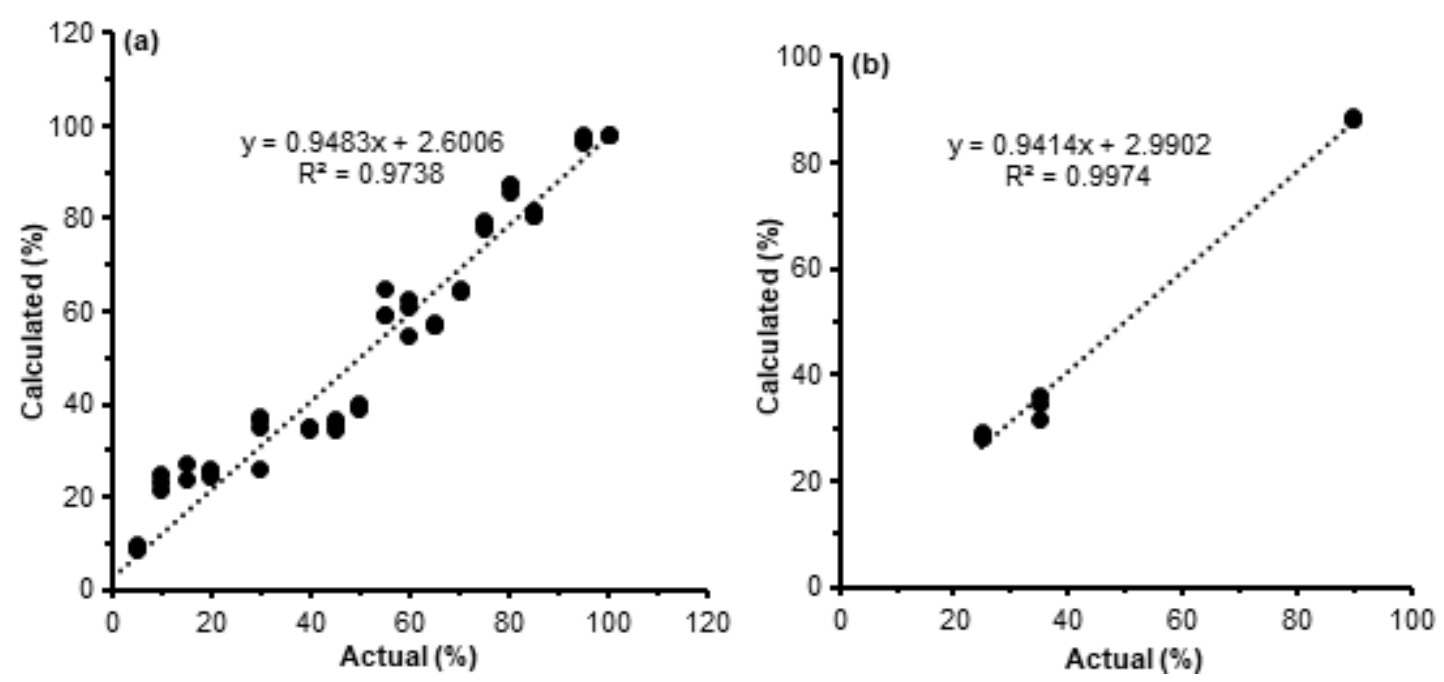

Fig 3. Partial least square regression for the relationship between actual values and FTIR calculated values of patchouli oil in castor oil either in calibration or in validation samples (a) calibration model; (b) validation model

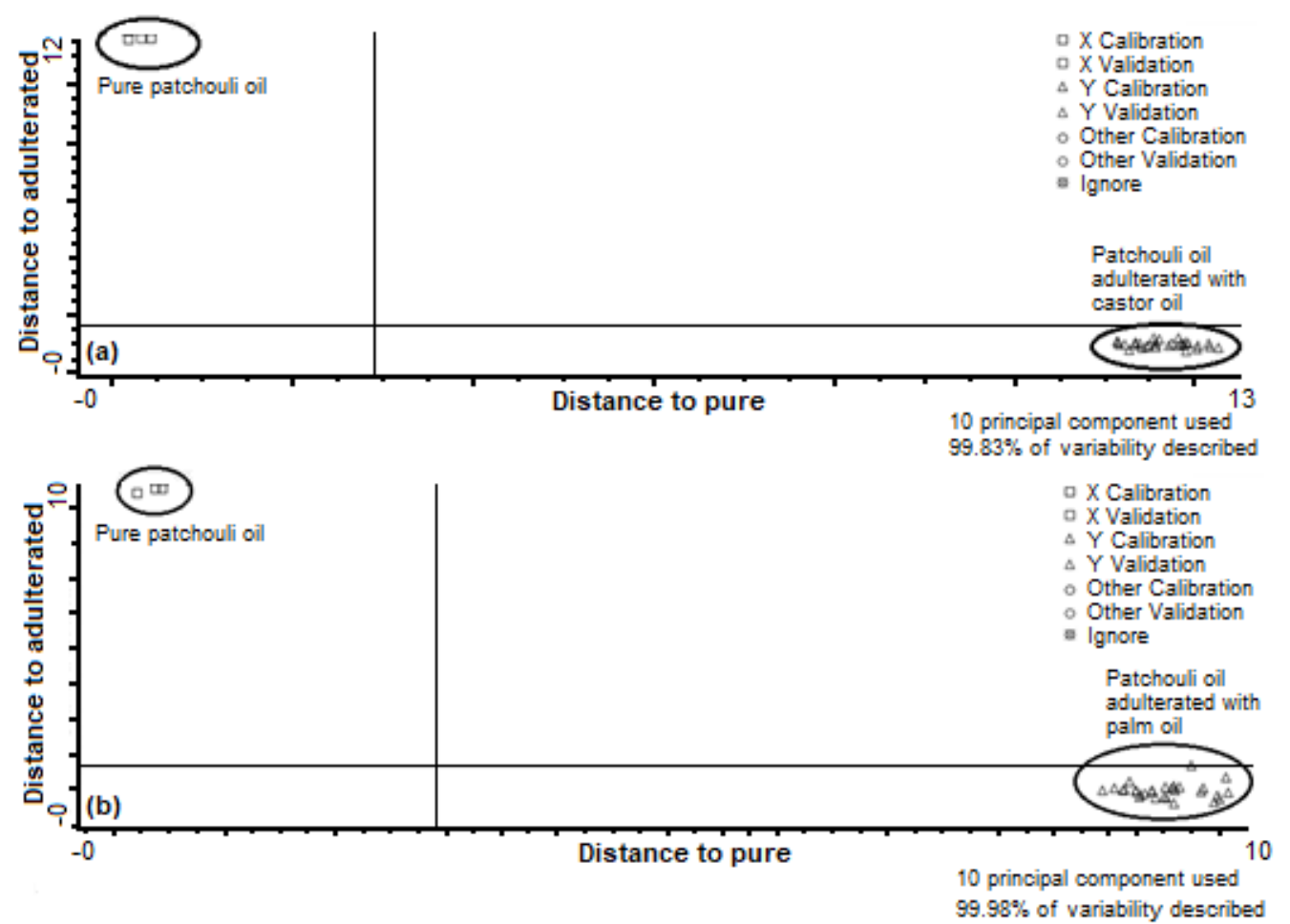

Fig 4. The Cooman plots obtained during discriminant analysis for classification of patchouli oil and that adulterated with (a) castor oil and (b) palm oil

\section{Discriminant Analysis}

In order to classify patchouli oil and that adulterated with castor oil and palm oil, discriminant analysis was used. DA is one of supervised pattern recognition technique [21]. The Mahalanobis distance using absorbancies at wavenumbers of $3933-717 \mathrm{~cm}^{-1}$ were used as variables during classification of pure oil and that adulterated with DA. Fig. 4 revealed the Cooman's plot for classification results. DA can successfully classified patchouli oil and that adulterated with castor oil [A] and that adulterated with palm oil [B] with $100 \%$ accuracy level. Misclassification may accord if variables 
used were not appropriate or the studied oils (authentic and adulterated oils) had very close similarity [22]. This indicated that DA was an effective tools for classification of oils for authentication purposes.

\section{- CONCLUSION}

FTIR spectroscopy in combination with chemometrics of PLS regression and DA using certain wavenumbers region has been successfully used for authentication of patchouli oil from castor oil and palm oil. The developed method was rapid, ease in sample preparation, and not involving excessive solvents and reagents.

\section{- ACKNOWLEDGMENTS}

The authors thank to the Ministry of Research, Technology and Higher Education, Republic Indonesia for partial financial assistance during this study via Hibah Penelitian Unggulan Perguruan Tinggi (PUPT) 2017 with contract number 2328/UN1.P.III/DIT-LIT/LT/2017.

\section{- REFERENCES}

[1] Zhu, B.C.R., Henderson, G., Yu, Y., and Laine, R.A., 2003, Toxicity and repellency of patchouli oil and patchouli alcohol against formosan subterranean termites Coptotermes formosanus Shiraki (Isoptera: Rhinotermitidae), J. Agric. Food Chem., 51 (16), 4585-4588.

[2] Akhila, A., and Tewari, R., 1984, Chemistry of patchouli oil: A review, Curr. Res. Med. Arom. Plants, 6, 38-54.

[3] Su, Z., Liao, J., Liu, Y., Liang, Y., Chen, H., Chen, X., Lai, X., Feng, X., Wu, D., Zheng, Y., Zhang, X., and Li, Y., 2016, Protective effects of patchouli alcohol isolated from Pogostemon cablin on lipopolysacchride-induced acute lung injury in mice, Exp. Ther. Med., 11 (2), 674-682.

[4] Huang, X., Liu, R., and Liu, Lv, Q., 2009, The effect of patchouli alcohol on oscopolamine-induced learninand memory impairment of mice, Chin. Tradit. Herbal Drugs, 40 (9), 1431-1433

[5] Jeong, J.B., Choi, J., Lou, Z., Jiang, X., and Lee, S.H., 2013, Patchouli alcohol, an essential oil of Pogostemon cablin, exhibits anti-tumorigenic activity in human colorectal cancer cells, Int. Immunopharmacol., 16 (2), 184-190.

[6] Li, Y.C., Peng, S.Z., Chen, H.M., Zhang, F.X., Xu, P.P., Xie, J.H., He, J.J., Chen, J.N., Lai, X.P., and Su, Z.R., 2012, Oral administration of patchouli alcohol isolated from Pogostemonis herba augments protection against influenza viral infection in mice, Int. Immunopharmacol., 12 (1), 294-301.

[7] Kocevski, D., Du, M., Kan, J., Jing, C., Lačanin, I., and Pavlović, H., 2013, Antifungal effect of Allium tuberosum, Cinnamomum cassia, and Pogostemon cablin essential oils and their components against population of Aspergillus species, J. Food Sci., 78 (5), M731-M737.

[8] Swamy, M.K., Akhtar, M.S., and Sinniah, U.R., 2016, Antimicrobial properties of plant essential oils against human pathogens and their mode of action: An updated review, Evid. Based Complementary Altern. Med., 2016, 3012462.

[9] Bae, S.Y., Lee, E.J., Son, R.H., and Lee, Y.H., 2009, The inhibitory effects of Pogostemon cablin Bentham extract on melanogenesis, J. Soc. Cosmet. Sci. Korea, 35 (1), 33-39.

[10] Do, T.K.T., Hadji-Minaglou, F., Antoniotti, S., and Fernandez, X., 2015, Authenticity of essential oils, TrAC, Trends Anal. Chem., 66, 146-157.

[11] Salgueiro, L., Martins, A.P., and Correia, H., 2010, Raw materials: The importance of quality and safety. A review, Flavour Fragrance J., 25, 253-271.

[12] Goodner, K., and Rouseff, R., 2011, Practical Analysis of Flavor and Fragrance Materials, John Wiley \& Sons Ltd., Chichester.

[13] Juliani, H.R., Kapteyn, J., Jones, D., Koroch, A.R., Wang, M., Charles, D., and Simon, J.E., 2006, Application of near-infrared spectroscopy in quality control and determination of adulteration of African essential oils, Phytochem. Anal., 17, 121128.

[14] König, W.A., and Hochmuth, D.H., 2004, Enantioselective gas chromatography in flavor and fragrance analysis: Strategies for the identification of known and unknown plant volatiles, $J$. Chromatogr. Sci., 42 (8), 423-439. 
[15] Schipilliti, L., Tranchida, P.Q., Sciarrone, D., Russo, M., Dugo, P., Dugo, G., and Mondello, L., 2010, Genuineness assessment of mandarin essential oils employing gas chromatography-combustion-isotope ratio MS (GC-C-IRMS), J. Sep. Sci., 33 (4-5), 617625.

[16] Rohman, A., and Man, Y.B.C., 2012, The chemometrics approach applied to FTIR spectral data for analysis of rice bran oil in extra virgin olive oil, Chemom. Intell. Lab. Syst., 110 (1), 129-134.

[17] Gjerstad, G., 1961, Spectrophotometric identification and evaluation of volatile oils, Planta Med., 9 (3), 245-250.

[18] Elzey, B., Norman, V., Stephenson, J., Pollard, D., and Fakayode, S.O., 2016, Purity analysis of adulterated essential oils by FT-IR spectroscopy and partial-least-squares regression, Spectroscopy, 31, 2637.

[19] Schulz, H., Quilitzsch, R., and Krüger, H., 2016, Rapid evaluation and quantitative analysis of thyme, origano and chamomile essential oils by ATR-IR and NIR spectroscopy, J. Mol. Struct., 661-662, 299-306.
[20] Li, S., Zhu, X., Zhang, J., Li, G., Su, D., and Shan, Y., 2012, Authentication of pure camellia oil by using near infrared spectroscopy and pattern recognition techniques, J. Food Sci., 77 (4), C374-C380.

[21] Manaf, M.A., Man, Y.B.C., Hamid, N.S.A., Ismail, A., and Abidin, S.Z., 2007, Analysis of adulteration of virgin coconut oil by palm kernel olein using Fourier transform infrared spectroscopy, J. Food Lipids, 14 (2), 111-121.

[22] Miller, J.N., and Miller, J.C., 2005, Statistics and Chemometrics for Analytical Chemistry, $5^{\text {th }}$ ed., Pearson Education, Essex, England.

[23] Guillén, M.D., and Cabo, N., 1997, Characterization of edible oils and lard by Fourier transform infrared spectroscopy. Relationships between composition and frequency of concrete bands in the fingerprint region, J. Am. Oil Chem. Soc., 74 (10), 1281-1286.

[24] Lerma-García, M.J., Ramis-Ramos, G., HerreroMartínez, J.M., and Simó-Alfonso, E.F., 2010, Authentication of extra virgin olive oils by Fouriertransform infrared spectroscopy, Food Chem., 118 (1), 78-83. 